\title{
Ocean acidification and food limitation combine to suppress herbivory by the gastropod Lacuna vincta
}

\author{
Craig S. Young, Alyson Lowell, Bradley Peterson, Christopher J. Gobler*
}

School of Marine and Atmospheric Sciences, Stony Brook University, Southampton, NY 11968, USA

\begin{abstract}
While ocean acidification has different effects on herbivores and autotrophs, how acidification may influence herbivory is poorly understood. This study examined how grazing by the gastropod Lacuna vincta (hereafter Lacuna) on the macroalgae Ulva spp. (hereafter Ulva) is influenced by ocean acidification. Herbivory by Lacuna was significantly reduced under elevated partial pressure of carbon dioxide $\left(p \mathrm{CO}_{2} ; 1500-2000 \mu \mathrm{atm}\right)$ relative to ambient $p \mathrm{CO}_{2}(\sim 400 \mu \mathrm{atm})$. This significant decrease in herbivory was unrelated to the physiological status of Ulva but rather was specifically elicited when Lacuna was exposed to elevated $p \mathrm{CO}_{2}$ in the absence of food for 18 to $24 \mathrm{~h}$ prior to grazing Ulva. The negative effects of elevated $p \mathrm{CO}_{2}$ on Lacuna were absent at 400 to $800 \mu \mathrm{atm} p \mathrm{CO}_{2}$ or when fed but persisted for up to $72 \mathrm{~h}$ following a $24 \mathrm{~h}$ exposure to elevated $p \mathrm{CO}_{2}$ without food. Depressed respiration rates in Lacuna following exposure to high $p \mathrm{CO}_{2}$ without food indicated these conditions produced metabolic suppression potentially associated with acidosis. Collectively, the lasting $(72 \mathrm{~h})$ nature of grazing inhibition of Lacuna following brief exposure $(18 \mathrm{~h})$ to moderate $p \mathrm{CO}_{2}$ levels $(>\sim 1500 \mu \mathrm{atm})$ when food was not available suggests this process could have broad effects on the dynamics of macroalgae in estuaries where Lacuna is a dominant grazer; these effects will be amplified as climate change progresses.
\end{abstract}

KEY WORDS: Ocean acidification $\cdot$ Gastropods $\cdot$ Macroalgae $\cdot$ Grazing

\section{INTRODUCTION}

The progressive delivery of $\mathrm{CO}_{2}$ into surface oceans is depressing levels of $\mathrm{pH}_{1} \mathrm{CO}_{3}{ }^{2-}$, and the saturation states of calcite $\left(\Omega_{\text {calcite }}\right)$ and aragonite $\left(\Omega_{\text {aragonite }}\right.$ ) (Doney et al. 2009, Feely et al. 2009). Beyond this process of ocean acidification, coastal zones can experience further acidification via upwelling, riverine discharge, and eutrophicationaccelerated microbial respiration (Feely et al. 2008, Cai et al. 2011, Melzner et al. 2013, Wallace et al. 2014). In many cases, the seasonal accumulation of $\mathrm{CO}_{2}$ in some modern coastal zones can create levels that exceed those projected by the year 2100 (>1000 uatm) (Feely et al. 2008, Melzner et al. 2013, Wallace et al. 2014).

\footnotetext{
${ }^{*}$ Corresponding author: christopher.gobler@stonybrook.edu
}

Ocean acidification is deleterious to a variety of calcifying organisms, including corals (Kleypas et al. 1999), coralline algae (Gao \& Zheng 2010), echinoderms (Wood et al. 2008), bivalves (Gazeau et al. 2007, Talmage \& Gobler 2011), and other molluscs, including gastropods (Shirayama \& Thorton 2005, Coleman et al. 2014). For gastropods, reduced $\mathrm{pH}$ and/or elevated $\mathrm{CO}_{2}$ levels have been shown to reduce fertility (Hendriks et al. 2010), shell growth (Shirayama \& Thorton 2005), and metabolism (Melatunan et al. 2011), with depressed metabolic rates potentially related to an increased reliance on anaerobic metabolism (Bishop \& Brand 2000, Seibel \& Walsh 2003). Furthermore, elevated partial pressure of carbon dioxide $\left(p \mathrm{CO}_{2}\right)$ can create conditions chemically unfavorable for shell

() The authors 2019. Open Access under Creative Commons by Attribution Licence. Use, distribution and reproduction are unrestricted. Authors and original publication must be credited. 
synthesis (Manno et al. 2012). Such adverse reactions to ocean acidification juxtapose those of some marine autotrophs, such as seagrasses (Palacios \& Zimmerman 2007, Young et al. 2018), phytoplankton (Fu et al. 2012, Hattenrath-Lehmann et al. 2015), and macroalgae (Hepburn et al. 2011, Young \& Gobler 2016), that may benefit from increased $p \mathrm{CO}_{2}$.

While the effects of ocean acidification on the growth and/or survival of various marine herbivores or autotrophs in isolation have been well studied during the past decade, little is known regarding the effects of elevated $\mathrm{CO}_{2}$ on autotroph-herbivore interactions. Previous studies have found that for numerous autotrophs, elevated $p \mathrm{CO}_{2}$ can alter tissue $\mathrm{C}: \mathrm{N}$ ratios by increasing non-structural carbohydrates (Fonseca et al. 1997, Zimmerman et al. 1997) or by enhancing $\mathrm{C}$ or $\mathrm{N}$ assimilation (Xu et al. 2010), which can affect palatability for grazers (Wakefield \& Murray 1998, Lapointe et al. 2004). Recent studies indicate that macroalgae such as Ulva can undergo rapid growth and assimilation of $\mathrm{C}$ and $\mathrm{N}$ under eutrophic and acidified conditions (Pedersen \& Borum 1997, Wallace \& Gobler 2015, Young \& Gobler 2016). As such, gastropods could ultimately benefit from enhanced macroalgal growth under eutrophic and acidified conditions.

The northern Lacuna snail Lacuna vincta (Gastropoda) is a common grazer in Northwest Atlantic coastal ecosystems that consumes various genera of macroalgae including Laminaria and Ulva (BradyCampbell et al. 1984, Chavanich \& Harris 2002, Nelson et al. 2008). In ecosystems where L. vincta is abundant, it can consume up to $25 \%$ of macroalgal productivity (Nelson et al. 2008, Molis et al. 2010). Few, if any, studies have assessed how grazing by $L$. vincta is affected by elevated $p \mathrm{CO}_{2}$. Given that some genera of macroalgae, such as Ulva, benefit from ocean acidification (Olischläger et al. 2013, Young \& Gobler 2016), and given L. vincta's preference for this alga (Nelson et al. 2008), it is important to understand how acidification may affect grazer-autotroph interactions (Falkenberg et al. 2013).

The objective of this study was to assess how elevated $p \mathrm{CO}_{2}$ affects the grazing behavior of $L$. vincta feeding on Northwest Atlantic populations of the macroalgae Ulva. A series of experiments was performed to quantify changes in grazing following exposure to elevated $p \mathrm{CO}_{2}$ and to determine if altered herbivory was associated with changes within the macroalgae or the grazers. Multiple levels and durations of exposure to elevated $p \mathrm{CO}_{2}$ were assessed in parallel with co-stressors for the snail (e.g. starvation) to obtain a refined understanding of how acidification may alter grazing by L. vincta.

\section{MATERIALS AND METHODS}

\subsection{Collection and preparation of Lacuna vincta and Ulva}

Ulva and L. vincta used for this study were collected from Shinnecock Bay, NY, USA $\left(40.85^{\circ} \mathrm{N}\right.$, $72.50^{\circ} \mathrm{W}$; Fig. S1 in the Supplement at www.int-res. com/articles/suppl/m627p083_supp.pdf) during low tide. Large, well-pigmented fronds of Ulva and L. vincta were collected by hand, placed in seawaterfilled containers, and transported to the Stony Brook Southampton Marine Science Center within $15 \mathrm{~min}$ of collection. Upon arrival at the facility, L. vincta were placed in a 201 polycarbonate vessel filled with filtered $\left(0.2 \mu \mathrm{m}\right.$ polysulfone filter capsule, Pall $\left.{ }^{\circledR}\right)$ seawater taken from the collection site. Aeration was supplied, and recently collected Ulva was introduced as a food source until experiments were initiated. Consistent with our previous sequencing efforts and microscopy (Young \& Gobler 2016), Ulva samples were confirmed as Ulva rigida. L. vincta are known to be an abundant macroalgae grazer in estuaries of the northeastern US (Chavanich \& Harris 2002, Janiak \& Whitlatch 2012) and were identified based on morphology. For this study, we refer to the algae as Ulva due to the inconsistent macroalgal taxonomic nomenclature as well as sequencing similarities within the internal transcribed spacer region of the ribosome of Ulva species (Kirkendale et al. 2013). We refer to L. vincta as Lacuna for the sake of consistency.

For all experiments, circular sections $(\sim 3.5 \mathrm{~cm}$ in diameter) of Ulva were cut from large thalli with care taken to avoid the potentially reproductive outer region of the organism (Wallace \& Gobler 2015). All samples were placed in a salad spinner to remove debris and epiphytes, extensively rinsed with filtered seawater, and spun again to further remove any debris and epiphytes (Young \& Gobler 2016). Samples were placed on a flat white board with a scale and a transparency film placed over the samples. A PVC cylinder was used to flatten the samples, taking care to eliminate creases in the samples but without causing any tears. A digital camera was used to image capture the samples, and the images were analyzed using ImageJ software, with the scale of each image individually calibrated. This procedure was performed 15 min prior to the introduction of Ulva in experiments (described in Section 2.3). 


\subsection{Preparation of experiments}

Thirteen experiments were performed, in series, to assess the effects of elevated $p \mathrm{CO}_{2}$ on the grazing behavior of Lacuna on Ulva. All experiments were performed in 11 polycarbonate vessels that were acid washed $(10 \% \mathrm{HCl})$ and liberally rinsed with deionized water prior to use. Experimental vessels were placed in an environmental control chamber set to a temperature $\left(20-23^{\circ} \mathrm{C}\right)$, light intensity (300-500 $\mu \mathrm{E}$ $\mathrm{m}^{-2} \mathrm{~s}^{-1}$ ), and duration (14 h light:10 h dark cycle) that matched ambient conditions observed at the collection site and optimal conditions for the animals and algae. Vessels were filled with filtered seawater and randomly assigned, in quadruplicate, to each treatment, which varied based on the experiment performed. Two additional containers were filled with filtered seawater and assigned to each treatment, without Lacuna, to assess residual Ulva growth. To minimize Ulva growth during the grazing period of the experiments, the lights in the environmental control chamber were turned off $24 \mathrm{~h}$ prior to the introduction of Lacuna (Nelson et al. 2008). For all grazing experiments, 8 Lacuna ( 2 $\mathrm{mm}$ ) were added to each vessel. The number of Lacuna used mimicked densities found on Ulva assemblages at the collection site (0.5-1 grazer $\mathrm{cm}^{-2}$ ) and reported in the literature (Chenelot \& Konar 2007, Dubois \& Iken 2012).

Dissolved gases were delivered into each experimental container through aeration via air diffusers (Pentair) connected to $1 \mathrm{ml}$ polystyrene serological pipettes inserted into the bottom of each container and connected via Tygon tubing to an air source. Containers were subjected to varying $\mathrm{CO}_{2}$ levels via multitube gas proportionator systems (Cole Parmer ${ }^{\circledR}$ Flowmeter) that mixed ambient air with $5 \% \mathrm{CO}_{2}$ gas (Talmage \& Gobler 2011). The gases were mixed and delivered at a flow rate of $2500 \pm 5 \mathrm{ml} \mathrm{min}^{-1}$ through gang valves into the serological pipettes that were fit through an opening in the plexiglass used to cover the experimental containers, which resulted in bubbling rates that turned over the volume of the experimental containers $>1000$ times daily. Bubbling was initiated $3 \mathrm{~d}$ prior to the start of each experiment to allow $\mathrm{CO}_{2}$ levels and carbonate chemistry to reach a state of equilibrium. A Honeywell DuraFET III ionsensitive field-effect transistor-based solid-state $\mathrm{pH}$ sensor $( \pm 0.01 \mathrm{pH}$ unit, total scale) was used to measure $\mathrm{pH}$ within containers daily. Water samples were taken at the beginning and conclusion of experiments to directly measure dissolved inorganic carbon (DIC) within experimental containers. The samples were preserved using a saturated mercuric chloride
Table 1. Values of $\mathrm{pH}_{\text {total, }}$ temperature $\left({ }^{\circ} \mathrm{C}\right)$, salinity $\left(\mathrm{g} \mathrm{kg}^{-1}\right)$, partial pressure of carbon dioxide $\left(p \mathrm{CO}_{2} ; \mu \mathrm{tm}\right)$, total dissolved inorganic carbon (DIC; $\mu$ mol $\mathrm{kg}^{-1}$ seawater [SW]), $\mathrm{HCO}_{3}{ }^{-}\left(\mu \mathrm{mol} \mathrm{kg}{ }^{-1} \mathrm{SW}\right)$, total alkalinity $\left(\mu \mathrm{mol} \mathrm{kg}{ }^{-1} \mathrm{SW}\right)$, saturation state of calcite $\left(\Omega_{\text {calcite }}\right)$, and saturation state of aragonite $\left(\Omega_{\text {aragonite }}\right)$ for Expts 1 to 13 . Data values represent means \pm SD. Data for individual experiments appear in Table S1 in the Supplement

\begin{tabular}{|lcc|}
\hline Parameter & Ambient $\mathrm{CO}_{2}$ & Elevated $\mathrm{CO}_{2}$ \\
\hline $\mathrm{pH}_{\text {total }}$ & $8.04 \pm 0.10$ & $7.42 \pm 0.08$ \\
Temperature & $22.4 \pm 1.0$ & $22.4 \pm 1.1$ \\
Salinity & $29.5 \pm 0.8$ & $29.6 \pm 0.8$ \\
$p \mathrm{CO}_{2}$ & $443 \pm 119$ & $1911 \pm 371$ \\
$\mathrm{Total}^{-} \mathrm{DIC}$ & $1833 \pm 91$ & $2036 \pm 140$ \\
$\mathrm{HCO}_{3}{ }^{-}$ & $1676 \pm 94$ & $1932 \pm 132$ \\
$\mathrm{Alkalinity}$ & $2031 \pm 89$ & $2040 \pm 136$ \\
$\Omega_{\text {calcite }}$ & $3.61 \pm 0.54$ & $1.08 \pm 0.20$ \\
$\Omega_{\text {aragonite }}$ & $2.33 \pm 0.35$ & $0.70 \pm 0.13$ \\
\hline
\end{tabular}

solution and stored at $\sim 4^{\circ} \mathrm{C}$ until analysis on a VINDTA 3D delivery system coupled with a UIC Inc. coulometer (model CM5017O) as reported in Young et al. (2018). $\mathrm{CO}_{2}$ levels (Table 1) were calculated from measured levels of DIC, $\mathrm{pH}$, temperature, and salinity as well as the first and second dissociation constants of carbonic acid in seawater (Millero 2010) using the program CO2SYS (http://cdiac.ornl.gov/ ftop/co2sys/). Certified reference material (CRM; provided by A. Dickson, Scripps Institution of Oceanography, University of California, San Diego; batch $159=2027.14 \mu \mathrm{mol}$ DIC kg${ }^{-1}$ seawater) was used as a quality assurance of measure, and analyses only proceeded when recovery of CRM was 99.9 to $100 \%$.

\subsection{Experimental designs}

The first 2 experiments were performed to gauge the herbivory rates of Lacuna feeding on Ulva incubated under ambient ( 400 $\mu \mathrm{atm})$ and elevated ( 2000 $\mu \mathrm{atm}) p \mathrm{CO}_{2}$ (Table 2). For Expts 1 and 2, Ulva was incubated for $\sim 1 \mathrm{wk}$ under ambient and elevated $\mathrm{CO}_{2}$ concentrations. At the conclusion of the incubation period, Lacuna were moved to separate vessels without Ulva (i.e. starved) under ambient or elevated $p \mathrm{CO}_{2}(24 \mathrm{~h})$. Lacuna were introduced into Ulva-containing vessels with ambient or elevated $p \mathrm{CO}_{2}$ and allowed to graze for $24 \mathrm{~h}$. Two additional experiments (Expts 3 and 4; Table 2) were performed to quantify herbivory of Lacuna when starved and allowed to graze on Ulva that was not being preexposed to elevated $\mathrm{CO}_{2}$ conditions. Lacuna were starved for $24 \mathrm{~h}$ in ambient or elevated $p \mathrm{CO}_{2}$ and 
Table 2. Experiments with their respective starvation and grazing periods and conditions. Figs. S2, S3, \& S4 available in the Supplement. $p \mathrm{CO}_{2}$ : partial pressure of carbon dioxide

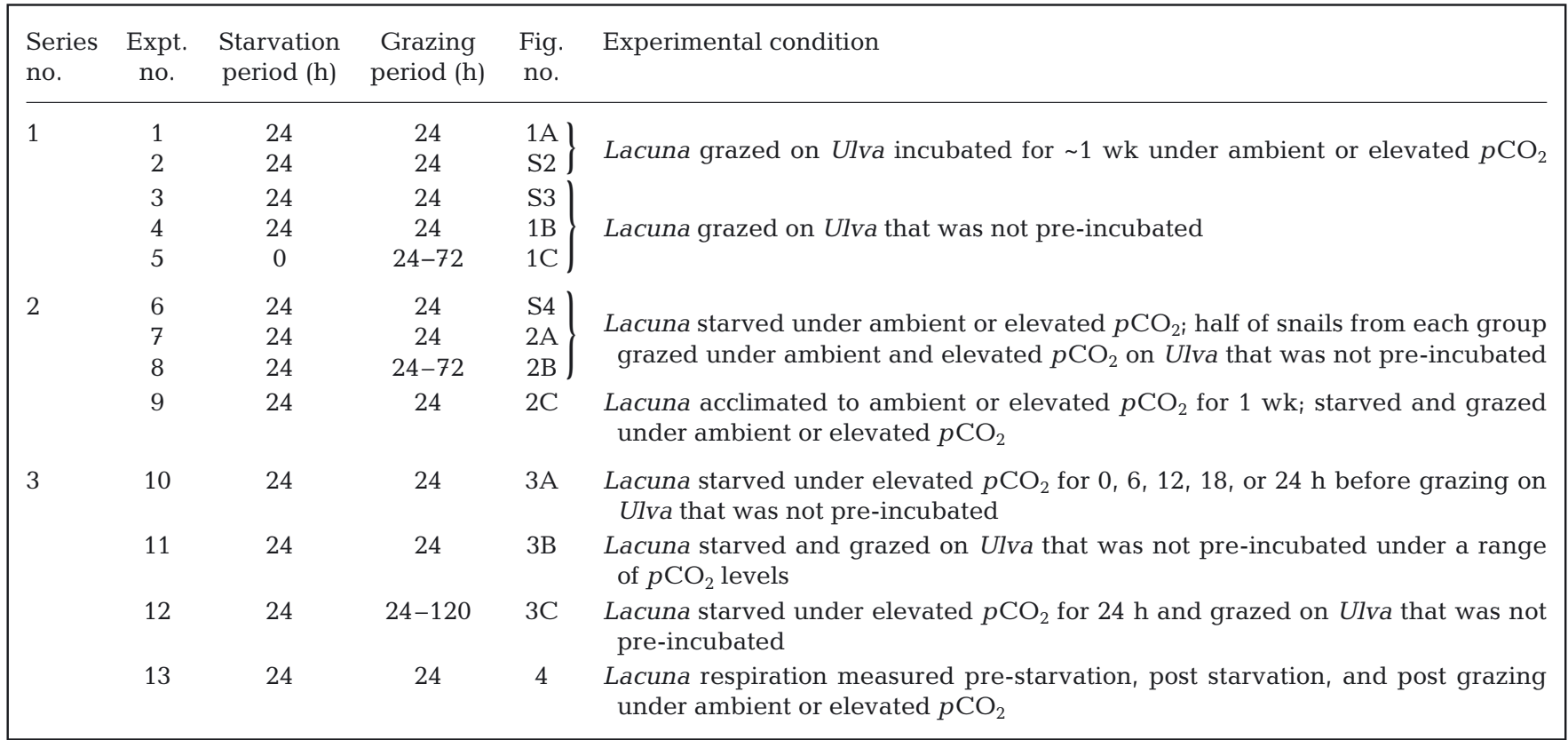

then placed into vessels with Ulva under ambient or elevated $p \mathrm{CO}_{2}$ for $24 \mathrm{~h}$. A fifth experiment (Expt 5; Table 2) followed the same procedure as Expts 3 and 4 , where Lacuna grazed on Ulva not exposed to elevated $\mathrm{CO}_{2}$, but the Lacuna were not starved for $24 \mathrm{~h}$ and were allowed to graze for up to $72 \mathrm{~h}$, with Ulva samples replaced, and herbivory was quantified every $24 \mathrm{~h}$. At the end of the grazing periods for all experiments, Lacuna and Ulva were removed from the vessels, and a digital camera was used to capture images of the Ulva with analysis using ImageJ as described in Section 2.1. Surface areas of Ulva samples grazed on by Lacuna were corrected for residual growth using the difference in surface area of Ulva samples without Lacuna. Herbivory rates were calculated by obtaining the difference in the initial and the final corrected surface areas divided by the number of grazers and the time elapsed of the grazing period $\left(\mathrm{mm}^{2}\right.$ grazer $\left.^{-1} \mathrm{~d}^{-1}\right)$.

A second set of experiments was performed to quantify herbivory rates of Lacuna when starved under ambient or elevated $p \mathrm{CO}_{2}$ and then allowed to graze on Ulva under ambient or elevated $p \mathrm{CO}_{2}$. During the 2 such reciprocal transplant experiments (Expts 6 and 7; Table 2), Lacuna were placed in ambient or elevated $p \mathrm{CO}_{2}$ and starved for $24 \mathrm{~h}$ as described above. At the end of the starvation period, the lights of the environmental chamber were turned off, and half of the Lacuna from both $\mathrm{CO}_{2}$ treatments were intro- duced into Ulva-containing vessels with the same $\mathrm{CO}_{2}$ level that they were starved in, while the other half were placed in containers with the opposite $\mathrm{CO}_{2}$ level, for a total of 4 treatments: a control with Lacuna that were starved and grazed in ambient $p \mathrm{CO}_{2}$, a treatment with Lacuna starved in ambient $p \mathrm{CO}_{2}$ that grazed in elevated $p \mathrm{CO}_{2}$, a treatment with Lacuna starved in elevated $p \mathrm{CO}_{2}$ that grazed in ambient $p \mathrm{CO}_{2}$, and a treatment with Lacuna that were starved and grazed in elevated $p \mathrm{CO}_{2}$. Ulva was exposed to only ambient $\mathrm{CO}_{2}$ conditions prior to the start of the experiments. Once in their respective containers, $\mathrm{La}$ cuna could graze for $24 \mathrm{~h}$. A similar procedure was used for Expt 8, with the only modification being that Lacuna were starved for $24 \mathrm{~h}$ and then allowed to graze for $72 \mathrm{~h}$, with Ulva pre-conditioned at ambient $p \mathrm{CO}_{2}$, replaced every $24 \mathrm{~h}$, and processed to quantify herbivory (Table 2). Expt 9 was similar to Expts 6 to 8 except that Lacuna were placed in ambient or elevated $p \mathrm{CO}_{2}$ with Ulva and allowed to acclimate for $1 \mathrm{wk}$ prior to the $24 \mathrm{~h}$ starvation period (Table 2). At the end of the starvation period, the lights of the environmental chamber were turned off, and Lacuna were introduced into Ulva-containing vessels with elevated or ambient $p \mathrm{CO}_{2}$ and allowed to graze for $24 \mathrm{~h}$ on Ulva that was previously exposed to only ambient $\mathrm{CO}_{2}$ conditions prior to the start of the experiment. At the end of the grazing periods, Lacuna and Ulva were removed, and grazing rates were calculated. 
The final set of experiments (Expts 10-13; Table 2) were performed to produce a refined sense of how $\mathrm{CO}_{2}$ exposure altered herbivory in Lacuna. These experiments specifically quantified the effective minimum dose of $\mathrm{CO}_{2}$ to alter herbivory rates of Lacuna, assessed the effective minimum duration of elevated $\mathrm{CO}_{2}$ exposure required to alter rates of herbivory, and assessed the duration of $\mathrm{CO}_{2}$-altered grazing post exposure. For Expt 10, which altered the duration of high $\mathrm{CO}_{2}$ exposure, 5 treatments were established: a control with ambient $\mathrm{CO}_{2}$ during the $24 \mathrm{~h}$ starvation period (no dose); a treatment with elevated $p \mathrm{CO}_{2}$ during the entire $24 \mathrm{~h}$ starvation period; and treatments with 6,12 , and $18 \mathrm{~h}$ of elevated $p \mathrm{CO}_{2}$ exposure during the starvation period with 18,12 , and 6 h, respectively, of ambient $p \mathrm{CO}_{2}$ exposure prior to the elevated $p \mathrm{CO}_{2}$ exposure. At the end of the starvation period, Lacuna were transferred to containers with ambient $p \mathrm{CO}_{2}$, Ulva samples were introduced, and Lacuna could graze for $24 \mathrm{~h}$, after which rates of herbivory were quantified. For Expt 11, 4 treatments were established: a control with ambient $p \mathrm{CO}_{2}(\sim 400 \mu \mathrm{atm})$, a moderate $p \mathrm{CO}_{2}$ treatment $(\sim 850 \mu \mathrm{atm})$, an elevated $p \mathrm{CO}_{2}$ treatment $(\sim 1500 \mu \mathrm{atm})$, and a high $\mathrm{pCO}_{2}$ treatment $(\sim 2050 \mu \mathrm{atm})$. For this experiment, Lacuna were placed in one of the $4 \mathrm{CO}_{2}$ treatments and starved for $24 \mathrm{~h}$. At the end of the starvation period, Ulva samples were introduced, and Lacuna could graze for $24 \mathrm{~h}$ at their respective $\mathrm{CO}_{2}$ levels. At the end of the $24 \mathrm{~h}$ grazing period, Ulva samples were removed, a new set of Ulva samples were introduced, and Lacuna could graze for another $24 \mathrm{~h}$ (48 $\mathrm{h}$ total), and after that $24 \mathrm{~h}$ period, the process was repeated ( $72 \mathrm{~h}$ total). Herbivory was quantified in each vessel from each time point at each level of $\mathrm{CO}_{2}$. For Expt 12, the starvation period lasted $24 \mathrm{~h}$, during which Lacuna were starved under ambient and elevated $p \mathrm{CO}_{2}$ but could graze only under ambient $p \mathrm{CO}_{2}$ during the grazing period, which persisted for $120 \mathrm{~h}$, with new Ulva samples introduced every $24 \mathrm{~h}$ (Table 2). At the end of the grazing periods for all experiments, Lacuna and Ulva were removed, and rates of herbivory were quantified.

A single experiment (Expt 13; Table 2) was performed to measure respiration rates of 2 Lacuna groups that were exposed to 3 successive conditions: when incubated under ambient $\mathrm{CO}_{2}$ levels with food, when starved for $24 \mathrm{~h}$ under elevated or ambient $\mathrm{CO}_{2}$ levels, and $24 \mathrm{~h}$ after grazing on Ulva under elevated or ambient $\mathrm{CO}_{2}$ levels. A PyroScience ${ }^{\circledR}$ Firesting $\mathrm{O}_{2}$ optical oxygen sensor was used to quantify changes in dissolved oxygen (DO) concentrations within $2 \mathrm{ml}$ respiration vials. Each vial was slowly filled with seawater from their respective treatments without bub- bling, and Lacuna from their respective treatments were carefully transferred to each vial. For each of the 3 experimental conditions, 5 Lacuna of similar size were selected and analyzed for each group. DO levels within each vial were recorded continuously for $3 \mathrm{~h}$, during which there were near-linear declines in DO with concentrations never declining by more than $50 \%$ or $<4 \mathrm{mg} \mathrm{l}^{-1}$. At the conclusion of the experiment, Lacuna dry tissue weights were obtained by weighing individuals after drying at $60^{\circ} \mathrm{C}$ for $72 \mathrm{~h}$, combusting them at $450^{\circ} \mathrm{C}$ for $4 \mathrm{~h}$, and weighing them again. Respiration rates were calculated using the changes in DO and dry tissue weight and were expressed as mg $\mathrm{O}_{2} \mathrm{~h}^{-1} \mathrm{~g}^{-1}$ dry tissue.

\subsection{Post-experimental analyses}

One-way ANOVA was performed within SigmaPlot 11.0 to assess significant differences in herbivory rates or, in the case of Expt 13, respiration rates under ambient and elevated $p \mathrm{CO}_{2}$ in Expts 1 to 5, 10, 11, and 13 (Table 2). Two-way ANOVA was performed within SigmaPlot to assess herbivory rates in Expts 6 to 9 and 12, where the main treatment effects were $p \mathrm{CO}_{2}$ during the starvation and grazing period (ambient or elevated for both; Expts 6-8), $p \mathrm{CO}_{2}$ during acclimation and the starvation and/or grazing period (ambient or elevated for both; Expt 8), and $p \mathrm{CO}_{2}$ during the starvation and/or grazing period (ambient, low, medium, and high) and time point (24, 48, and 72 h; Expt 12). Normality was tested via the use of Shapiro-Wilks tests within SigmaPlot 11.0. In the case of Expts 10,12, and 13, if significant differences were detected, a Tukey's HSD test using R 3.4.0 within RStudio 1.0.143 was performed.

\section{RESULTS}

\subsection{First experimental series: assessing the impact of high $\mathrm{CO}_{2}$}

Lacuna herbivory rates on Ulva were highly sensitive to changes in $p \mathrm{CO}_{2}$. For Expt 1 , herbivory rates were significantly lower in elevated $p \mathrm{CO}_{2}$ relative to ambient conditions, declining from $23 \mathrm{~mm}^{2}$ grazer $^{-1}$ $\mathrm{d}^{-1}$ to zero (1-way ANOVA; $\mathrm{p}<0.05$; Fig. 1A; Table S2). For Expt 2, herbivory rates under elevated $p \mathrm{CO}_{2}$ were $86 \%$ lower than within ambient treatments (1-way ANOVA; p < 0.05; Fig. S2; Table S2). During Expts 3 and 4, the sensitivity of Lacuna herbivory rates to high $\mathrm{CO}_{2}$ persisted, even when Ulva was 
not incubated under high $\mathrm{CO}_{2}$. In Expt 3, herbivory rates under elevated $p \mathrm{CO}_{2}$ decreased by $\sim 50 \%$ relative to ambient treatments (1-way ANOVA; $\mathrm{p}<0.05$; Fig. S3; Table S2). For Expt 4, herbivory rates within elevated $\mathrm{CO}_{2}$ treatments were close to zero and $\sim 12$ fold lower than herbivory rates in ambient $\mathrm{CO}_{2}$ treatments (1-way ANOVA; $\mathrm{p}<0.05$; Fig. 1B; Table S2). For Expt 5, when Lacuna was not starved before being allowed to graze on Ulva, elevated $p \mathrm{CO}_{2}$ did not significantly affect herbivory rates at the 24,48, or $72 \mathrm{~h}$ time points (1-way ANOVA; p > 0.05 for all; Fig. 1C; Table S2).

\subsection{Second experimental series: identifying the critical time of exposure}

For Expts 6, 7, and 8, Lacuna herbivory rates were found to be dependent on the $\mathrm{CO}_{2}$ concentrations in which they were starved in. In Expt 6, when Lacuna were starved under elevated $p \mathrm{CO}_{2}$, herbivory decreased by nearly 4 -fold relative to ambient treatments (2-way ANOVA; p < 0.05; Fig. S4; Table S3). Herbivory was not significantly changed by the $p \mathrm{CO}_{2}$ Lacuna were exposed to during the grazing

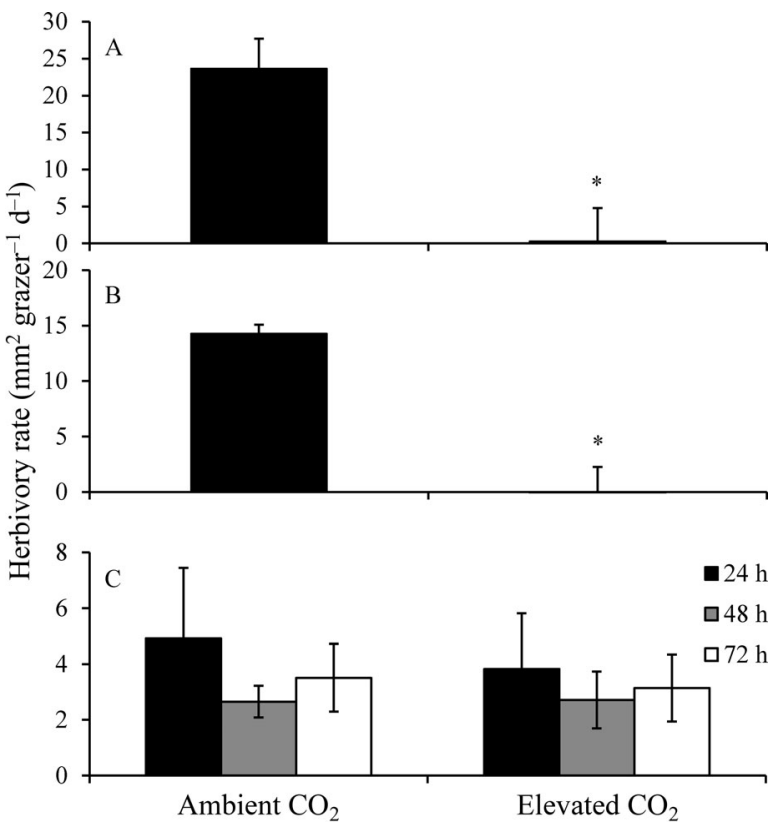

Fig. 1. Herbivory rates of Lacuna grazing on Ulva under ambient and elevated partial pressure of carbon dioxide $\left(p \mathrm{CO}_{2}\right)$ for (A) Ulva pre-incubated for $1 \mathrm{wk}$ under ambient and elevated $p \mathrm{CO}_{2}$ (Expt 1; Table 2), (B) Ulva not pre-incubated (Expt 4; Table 2), and (C) Ulva not pre-incubated and with-out a starvation period for Lacuna (Expt 5; Table 2). Asterisks represent significant differences between treatments $(p<0.05)$.

Bars and error bars represent means $\pm \mathrm{SD}$ period ( $p>0.05)$. In Expt 7, herbivory was reduced by 6 -fold when Lacuna were starved under elevated $p \mathrm{CO}_{2}$ (2-way ANOVA; $\mathrm{p}<0.05$; Fig. 2A; Table S3). Herbivory was not significantly affected by the $p \mathrm{CO}_{2}$ Lacuna were exposed to during the grazing period ( $p>0.05$ ). For Expt 8, herbivory was significantly lower for Lacuna after being exposed to elevated $p \mathrm{CO}_{2}$ during the starvation period at all time points (2-way ANOVA; $p<0.05$ for all; Fig. 2B; Table S3) but was not significantly affected by the $p \mathrm{CO}_{2}$ present when Lacuna grazed ( $p>0.05$ for all). During Expt 9, Lacuna herbivory rates were significantly lower by 5-fold when Lacuna were exposed to elevated $p \mathrm{CO}_{2}$ during the starvation and/or grazing period when $p \mathrm{CO}_{2}$ was kept constant for both periods
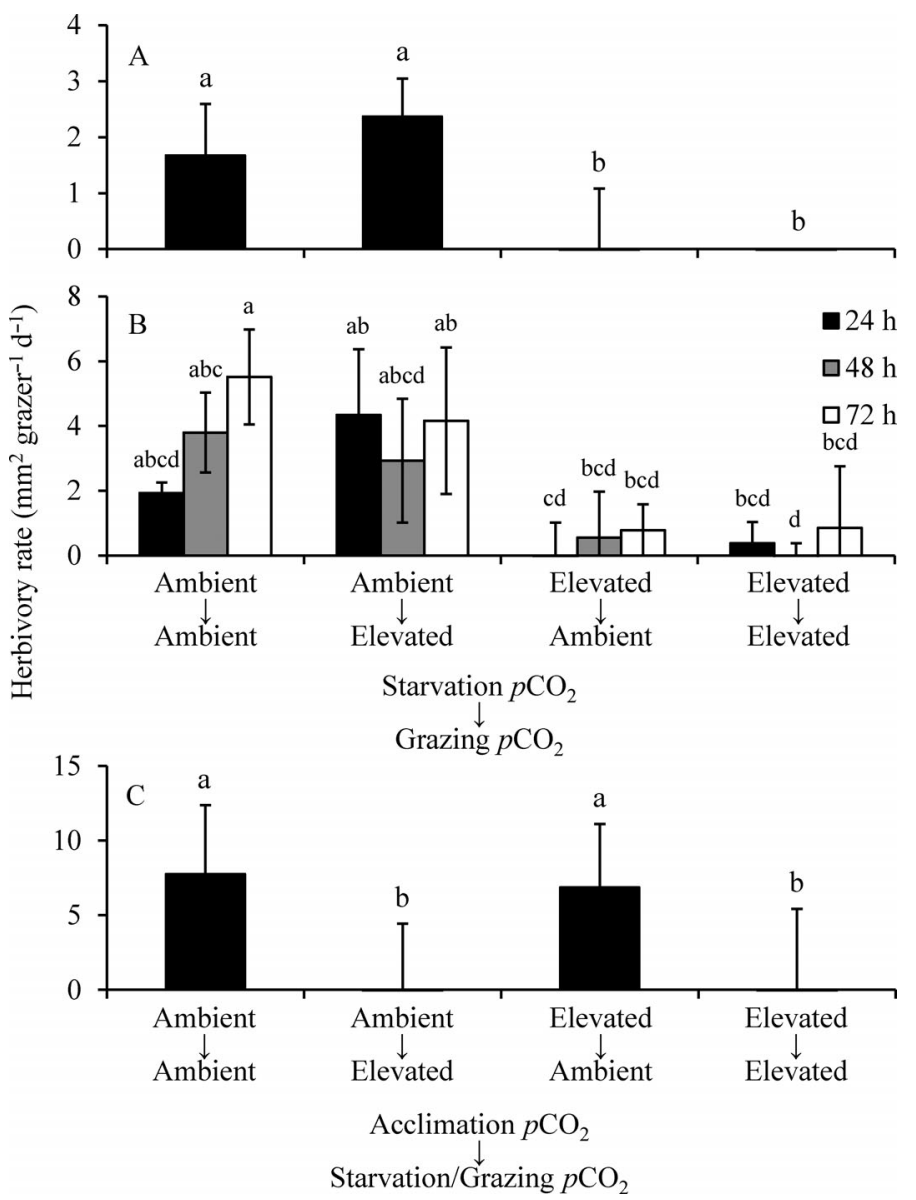

Fig. 2. Herbivory rates of Lacuna starved under ambient and elevated partial pressure of carbon dioxide $\left(p \mathrm{CO}_{2}\right)$ and allowed to graze on Ulva under both $\mathrm{CO}_{2}$ concentrations for (A) $24 \mathrm{~h}$ (Expt 7; Table 2), (B) 24 to $72 \mathrm{~h}$ (Expt 8; Table 2), or (C) 24 $\mathrm{h}$ following an initial $1 \mathrm{wk}$ to acclimate under ambient and elevated $p \mathrm{CO}_{2}$ (Expt 9; Table 2). Letters on bars represent significant differences among groups as determined by Tukey Honest Significant Difference tests performed for each $24 \mathrm{~h}$ grazing period. Bars and error bars represent means $\pm \mathrm{SD}$ 

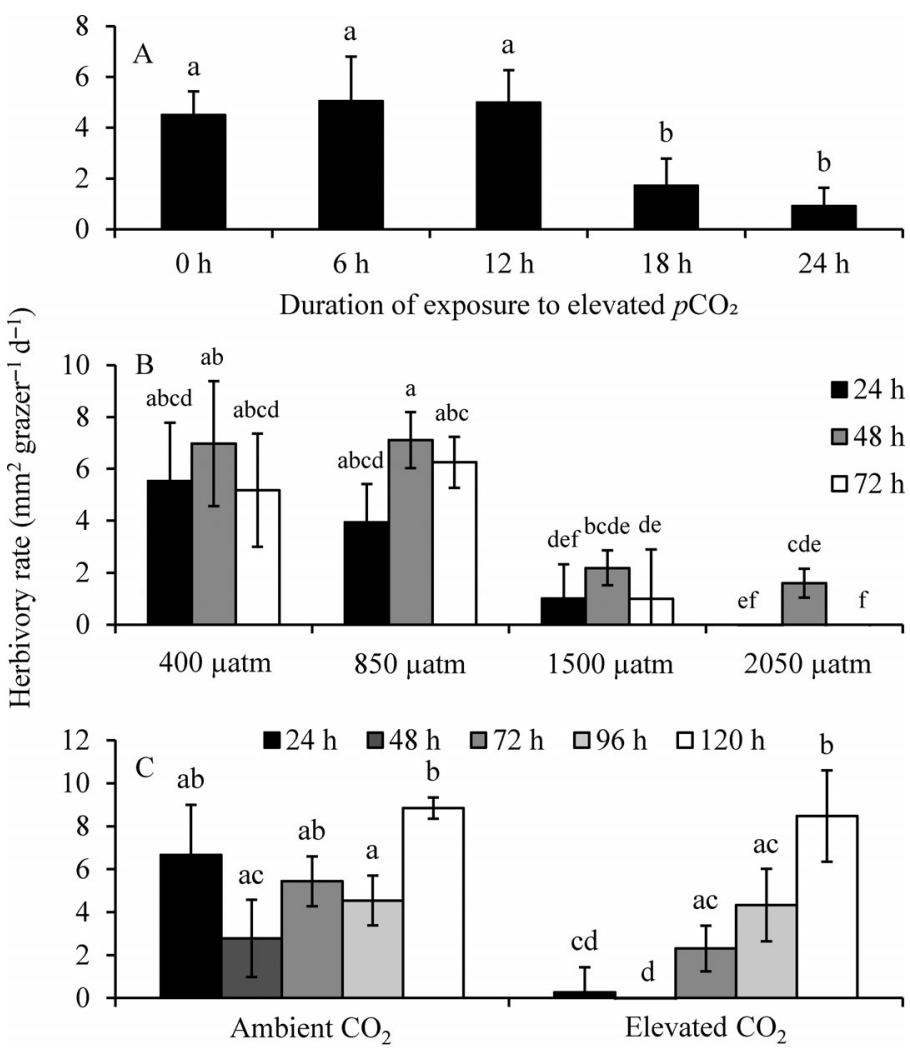

Fig. 3. Herbivory rates of Lacuna (A) starved for various lengths of time under ambient and elevated partial pressure of carbon dioxide $\left(p \mathrm{CO}_{2}\right.$; Expt 10; Table 2), (B) starved for $24 \mathrm{~h}$ and allowed to graze on Ulva under varying $p \mathrm{CO}_{2}$ for 24 to $72 \mathrm{~h}$ (Expt 11; Table 2), and (C) starved for $24 \mathrm{~h}$ under ambient or elevated $p \mathrm{CO}_{2}$ and allowed to graze on Ulva under only ambient $p \mathrm{CO}_{2}$ for 24 to $120 \mathrm{~h}$ (Expt 12; Table 2). Letters on bars represent significant differences among groups as determined by Tukey Honest Significant Difference tests

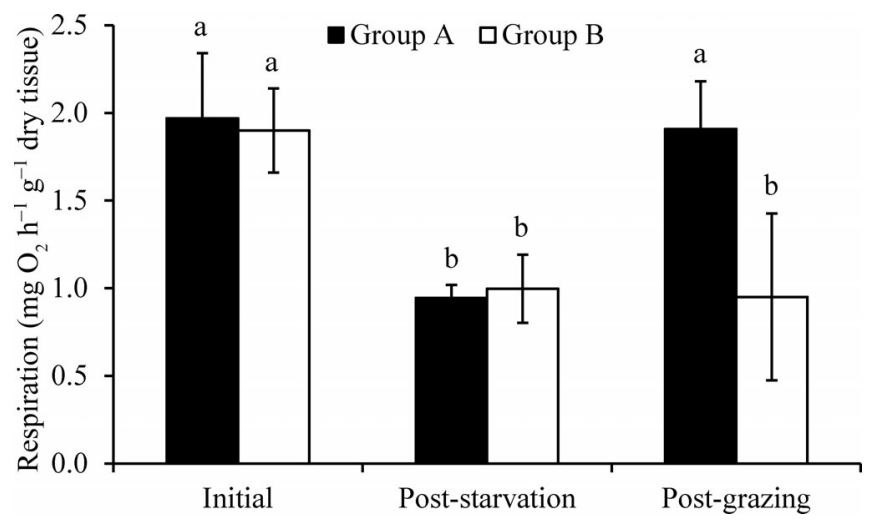

Fig. 4. Respiration rates of Lacuna following incubation under ambient partial pressure of carbon dioxide $\left(p \mathrm{CO}_{2}\right)$, post starvation, and post grazing for individuals starved under ambient or elevated $p \mathrm{CO}_{2}$ for $24 \mathrm{~h}$ (Groups A and B, respectively; Expt 13; Table 2). Significant differences between Group A and B represent p-values less than 0.05. Columns and error bars represent means $\pm \mathrm{SD}$

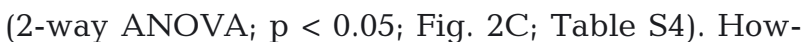
ever, herbivory was not significantly altered by the $p \mathrm{CO}_{2}$ when exposed $1 \mathrm{wk}$ prior to the experiment and supplied food ad libitum ( $\mathrm{p}>0.05)$.

\subsection{Third experimental series: assessing the minimal effective dose and respiration}

For Expt 10, herbivory rates differed significantly as a function of the duration of exposure to elevated $p \mathrm{CO}_{2}$ during the starvation period (1-way ANOVA; $\mathrm{p}<0.05$; Fig. 3A; Table S5). Herbivory rates of individuals exposed to elevated $p \mathrm{CO}_{2}$ for 18 and $24 \mathrm{~h}$ during the starvation period were significantly lower than rates for individuals exposed for 0,6 , and $12 \mathrm{~h}$ (Tukey's HSD; p $<0.05$ for all; Fig. 3A; Table S6). For Expt 11, herbivory rates were found to be inhibited by $p \mathrm{CO}_{2}$ in a dose-dependent manner, with rates under 1500 and $2050 \mu$ atm $p \mathrm{CO}_{2}$ being significantly and over 4 -fold lower than rates of individuals exposed to 400 and 850 ratm (Tukey's HSD; p $<0.05$ for both; Fig. 3B; Table S7). This trend persisted throughout the $72 \mathrm{~h}$ experiment ( $\mathrm{p}<0.05$ for both). During Expt 12, Lacuna starved under elevated $p \mathrm{CO}_{2}$ had significantly lower herbivory rates after 24,48 , and $72 \mathrm{~h}$ (1way ANOVA; $\mathrm{p}<0.05$ for all; Fig. 3C; Tables S8 \& S9), but the inhibitory effect dissipated by $96 \mathrm{~h}(\mathrm{p}>0.05)$.

Finally, in Expt 13, respiration rates of Lacuna were sensitive to elevated $p \mathrm{CO}_{2}$ and feeding. Prior to experimental exposure, respiration rates of 2 groups of Lacuna incubated under ambient $\mathrm{pCO}_{2}$ were not significantly different (1-way ANOVA; $\mathrm{p}>0.05$; Fig. 4; Tables S10 \& S11). Following the $24 \mathrm{~h}$ starvation period, the respiration rates of Lacuna starved under both ambient and elevated $p \mathrm{CO}_{2}$ were both $50 \%$ lower than before starvation but not significantly different from each other $(p>0.05)$. Following the $24 \mathrm{~h}$ grazing period, the respiration rates of Lacuna that were starved and grazed under ambient $p \mathrm{CO}_{2}$ were significantly higher than individuals under elevated $p \mathrm{CO}_{2}(\mathrm{p}<0.05)$.

\section{DISCUSSION}

During this study, herbivory rates of Lacuna were significantly reduced when snails were exposed to elevated $\mathrm{CO}_{2}$ concentrations and deprived of food. This occurred whether Ulva had been exposed to high or ambient $p \mathrm{CO}_{2}$ prior to the experiment. Allowing Lacuna to acclimate to elevated $p \mathrm{CO}_{2}$ for $1 \mathrm{wk}$ did not mitigate the suppression of herbivory. 
The response of Lacuna to the negative effects of elevated $p \mathrm{CO}_{2}$ and starvation did not occur linearly with increasing $\mathrm{CO}_{2}$ but rather declined at a threshold of $1500 \mu \mathrm{atm} p \mathrm{CO}_{2}$ or higher with an exposure of at least $18 \mathrm{~h}$ needed to significantly depress herbivory. Reduced herbivory persisted for $72 \mathrm{~h}$ following a $24 \mathrm{~h}$ exposure period to elevated $p \mathrm{CO}_{2}$, and starving and reductions in grazing were accompanied by lowered respiration rates. Collectively, this study revealed a novel mechanism by which acidification can disrupt a fundamental ecological process in coastal zones: gastropod herbivory on macroalgae.

Exposure to elevated $p \mathrm{CO}_{2}$ in the absence of food led to a metabolic depression in Lacuna as evidenced by lowered respiration rates. Consistent with our measurements, marine gastropods have been shown to experience significantly reduced respiration during prolonged periods of food limitation (Maas et al. 2011). Furthermore, lowered respiration and metabolic rates in response to elevated $\mathrm{CO}_{2}$ levels have been documented in other gastropods (Bibby et al. 2007, Hendriks et al. 2010, Melatunan et al. 2011) and other common estuarine organisms (Lindinger et al. 1984, Pörtner et al. 1998, Todgham \& Hofmann 2009). The gross growth efficiency for marine gastropods can be as low as $\sim 6 \%$ (Odum \& Smalley 1959) and is dependent on food supply (Carefoot 1967). Exposure to elevated $p \mathrm{CO}_{2}$ can cause acidosis, which can disrupt metabolism, homeostatic functions, and the function of energy transduction and divert energy from shell and somatic growth (Lindinger et al. 1984, Pörtner et al. 1998, Marchant et al. 2010). Depressed metabolism may also serve as a survival strategy to match the lowered energy supply (Bishop \& Brand 2000, Seibel \& Walsh 2003) available due to starvation and, potentially, an increased reliance on anaerobic respiration (Pörtner et al. 1998, Melatunan et al. 2011). In the present study, the suppression of grazing rates under elevated $p \mathrm{CO}_{2}$ and in the absence of food likely reflects a broad-scale suppression of Lacuna metabolism associated with concurrently experiencing acidosis and starvation.

Beyond the direct effects on herbivory in Lacuna, elevated $p \mathrm{CO}_{2}$ may have a multitude of other effects on this and other marine gastropods. The continued delivery of $\mathrm{CO}_{2}$ into coastal ecosystems is expected to negatively affect the growth and survival of gastropods and other calcifying organisms through reductions in the availability of carbonate. Exposure to elevated $p \mathrm{CO}_{2}$ and/or low $\mathrm{pH}$ conditions for prolonged periods of time has been shown to reduce shell growth, repair rates, and physiological integrity in numerous marine gastropods (Shirayama \& Thorton
2005, Bibby et al. 2007, Manno et al. 2012, Coleman et al. 2014). Lacuna are particularly vulnerable to reductions in $\Omega_{\text {calcite }}$ (Taylor \& Reid 1990) and may need to reallocate extra energy to counteract shell dissolution (Manno et al. 2012). As mentioned previously, diversion of energy toward maintenance of shell integrity may have contributed to metabolic depression in Lacuna in the present study.

While tissue $\mathrm{C}: \mathrm{N}$ ratios and anti-grazing compounds in macroalgae can be altered by elevated $p \mathrm{CO}_{2}$ (Gordillo et al. 2001, Young \& Gobler 2016) and may affect grazing behavior (Wakefield \& Murray 1998, Falkenberg et al. 2013), the exposure of Ulva to high $\mathrm{CO}_{2}$ prior to grazing did not alter herbivory rates of Lacuna during this study. Herbivory rates of Lacuna were significantly reduced when exposed to elevated $p \mathrm{CO}_{2}$ prior to feeding on Ulva that was grown under high or low $\mathrm{CO}_{2}$. Furthermore, grazing rates of Lacuna on Ulva under high $\mathrm{CO}_{2}$ were not reduced when the snails had not been starved for $24 \mathrm{~h}$ prior to grazing.

Beyond the delivery of $\mathrm{CO}_{2}$ via the combustion of fossil fuels, eutrophication-enhanced microbial respiration is a strong source of $\mathrm{CO}_{2}$ into coastal zones that can result in $p \mathrm{CO}_{2}$ that exceeds levels projected

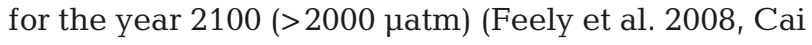
et al. 2011, Melzner et al. 2013, Wallace et al. 2014). While Ulva experienced enhanced growth under elevated $p \mathrm{CO}_{2}$ in this study (Fig. S5) and has been shown to experience enhanced growth under elevated $\mathrm{CO}_{2}$ and nutrient concentrations (Olischläger et al. 2013, Young \& Gobler 2016, Ober \& Thornber 2017), nutrient enrichment can reduce the abundances of numerous common estuarine grazers, including gastropods such as Lacuna, due to potentially toxic levels of ammonia (Atalah \& Crowe 2012). Furthermore, the proliferation, death, and decomposition of macroalgal mats can result in the accumulation of sulfides, significantly reducing DO concentrations (Hauxwell et al. 2001) and increasing levels of $p \mathrm{CO}_{2}$ (Wallace et al. 2014). During short-term hypoxic events, tolerance to hypoxia by marine gastropods is reduced by elevated hydrogen sulfide concentrations (Hiroki 1978), and as this study revealed, their respiration rates may decline in response to acidification. Given that Ulva is capable of undergoing rapid growth under eutrophic conditions (Pedersen \& Borum 1997, Wallace \& Gobler 2015) and the depression of Lacuna herbivory rates after exposure to excess $\mathrm{CO}_{2}$ when not actively grazing, it would seem that eutrophication and eutrophication-promoted acidification that inhibit grazing on Ulva could synergistically facilitate the proliferation of algal bio- 
mass and events known as green tides (Zhao et al. 2013) via both top-down and bottom-up processes. Moreover, elevated $\mathrm{CO}_{2}$, hypoxia, and high nutrient concentrations symptomatic of eutrophication may establish a positive feedback loop with regard to Ulva blooms in coastal zones in that the reduction of herbivory rates of Lacuna would facilitate the overgrowth of Ulva and, through the eventual decomposition of the algae, lead to the accumulation of $\mathrm{CO}_{2}$, sulfides, ammonia, and hypoxia zones that could collectively contribute to further declines in grazer abundance and herbivory rates, promoting continued macroalgal overgrowth.

In the present study, Lacuna herbivory rates did not decrease linearly with increasing $p \mathrm{CO}_{2}$ but rather declined after exposure to $1500 \mu \mathrm{atm}$, with the potential for negative effects to take effect above $850 \mu \mathrm{atm}$, which is within the range of projected $p \mathrm{CO}_{2}$ for world oceans as early as the end of the $21^{\text {st }}$ century (Doney et al. 2009, Feely et al. 2009). In the present study, $18 \mathrm{~h}$ of exposure to elevated $p \mathrm{CO}_{2}$ in the absence of food suppressed Lacuna herbivory rates, with the grazing suppression persisting for $72 \mathrm{~h}$. In an ecosystem context, this suggests that gastropods sensitive to elevated $p \mathrm{CO}_{2}$ may be vulnerable to both diurnal and seasonal shifts in $\mathrm{pH}$ and $p \mathrm{CO}_{2}$. Shallow eutrophic estuaries can become strongly net heterotrophic at night and during low tides, with acidified conditions sometimes persisting $18 \mathrm{~h}$ (O'Boyle et al. 2013, Wallace et al. 2014, Baumann et al. 2015). Such conditions are most common in temperate estuaries during late summer when high microbial respiration rates intensify benthic acidification, with declines in $\mathrm{pH}$ and $\Omega$ and increases in $p \mathrm{CO}_{2}$ above levels that negatively affected Lacuna in the present study ( $>1500 \mu \mathrm{atm})$ (Wallace et al. 2014). Such acidification is often coupled with hypoxia (Melzner et al. 2013, Wallace \& Gobler 2015), which may further exacerbate deleterious effects on herbivory rates (Melatunan et al. 2011, Russell et al. 2013, Gobler \& Baumann 2016).

In the present study, Lacuna was tolerant of elevated $p \mathrm{CO}_{2}$ when fed ad libitum. Previous studies have found that growth and calcification of blue mussels Mytilus edulis (Melzner et al. 2011, Thomsen et al. 2013) and other calcifying organisms (Pansch et al. 2014) were resistant to acidification when there was an abundance of food. Similarly, forage fish Menidia beryllina and Cyprinodon variegatus were found to be more vulnerable to the harmful effects of elevated $p \mathrm{CO}_{2}$ when their food supply was restricted (Gobler et al. 2018). Adequate food availability yielding optimal energy supplies may increase the likeli- hood that individuals will be able to upregulate the biochemical pathways needed to resist the negative effects of elevated $p \mathrm{CO}_{2}$ (Thomsen et al. 2013, Pansch et al. 2014). Given that Lacuna utilize macroalgae as a habitat and a food source (Martel \& Chia 1991, Chavanich \& Harris 2002), moderate levels of algae have the potential to minimize the harmful effects of exposure to acidification.

Macroalgae such as Ulva could partially mitigate the harmful effects of elevated $p \mathrm{CO}_{2}$ on gastropods. Beyond its role as a food source, Ulva may buffer carbonate chemistry through photosynthetic activity, serving as a refuge for organisms negatively affected by elevated $p \mathrm{CO}_{2}$ levels (Krause-Jensen et al. 2015, Wahl et al. 2018, Young \& Gobler 2018). Given that Lacuna were not significantly impacted by elevated $p \mathrm{CO}_{2}$ when able to graze on Ulva and that photosynthesis by Ulva can partly counteract acidification via photosynthesis (Young \& Gobler 2018), it seems likely that if Lacuna were exposed to elevated $p \mathrm{CO}_{2}$, a robust population of Ulva could create a refuge to protect Lacuna. The extent to which Ulva may mitigate the harmful effects of acidification on Lacuna is likely dependent on several factors including water residence time, water column depth, growth stage and abundance of Ulva, and extent of eutrophication. Deeper water bodies with rapid flushing times, poorly growing or scarce Ulva, and/or lower nutrient loading rates would be less likely to experience the carbonate buffering of macroalgae. Furthermore, the beneficial nature of Ulva could seasonally transform into a harmful effect for Lacuna when Ulva dies off and creates high $\mathrm{CO}_{2}$ and low food conditions potentially coupled with poor water quality (high ammonia and sulfides, low oxygen).

Reduced herbivory by grazers under elevated $p \mathrm{CO}_{2}$ could have consequences for other macroalgae. While Ulva is an important food source for Lacuna (Nelson et al. 2008), Lacuna and other marine gastropods also often consume laminarialean kelps due to their lower anti-grazing defenses (phlorotannins) and high palatability (Wakefield \& Murray 1998). As a common grazer in coastal Northwest Atlantic ecosystems (Chavanich \& Harris 2002, Janiak \& Whitlatch 2012) and the only mesograzer in the region known to consume macroscopic kelp sporophytes (Brady-Campbell et al. 1984, Johnson \& Mann 1986), large population increases in Lacuna can result in significant consumption of kelp blades and the loss of canopies of kelp beds in the Northwest Atlantic region (Fralick et al. 1974, Krumhansl \& Scheibling 2011). Elevated $p \mathrm{CO}_{2}$ is known to significantly enhance the growth of various kelp species 
(Swanson \& Fox 2007, Hepburn et al. 2011). If increased $\mathrm{CO}_{2}$ suppresses Lacuna herbivory on kelp, future $\mathrm{CO}_{2}$ increases associated with climate change may indirectly benefit kelp beds by both promoting growth and potentially reducing Lacuna herbivory rates.

In conclusion, exposure of Lacuna to elevated $p \mathrm{CO}_{2}$ in the absence of food reduced herbivory rates on Ulva. Reduced respiration rates of Lacuna following exposure to elevated $p \mathrm{CO}_{2}$ in the absence of food evidenced a metabolic depression as a response to these dual stressors. These impacts may be common in estuaries given that the threshold dose that elicited the effects $\left(18 \mathrm{~h}, 1500 \mu \mathrm{atm} p \mathrm{CO}_{2}\right)$ are found in many eutrophic estuaries during summer (Feely et al. 2008, Melzner et al. 2013, Wallace et al. 2014) and will be more common in the future (Doney et al. 2009). The lasting effect on grazing suppression $(72 \mathrm{~h})$ demonstrates that even ephemeral transitions into low food, high $\mathrm{CO}_{2}$ conditions could have lasting ecosystem ramifications. Reduced herbivory facilitated by acidification may limit the consumption of macroalgal biomass, allowing green tides to proliferate unchecked, ultimately promoting the accumulation of sulfides, hypoxia, and $\mathrm{CO}_{2}$ and perhaps further reducing topdown control of macroalgal biomass. The extent to which gastropods may be released from the negative effects of acidification by macroalgae buffering carbonate chemistry and providing food is unknown and warrants future investigation.

Acknowledgements. We are appreciative of the logistic support provided by the Stony Brook Southampton Marine Science Center staff throughout this study. Funding for these experiments was obtained from New York Sea Grant award R-FBM-38, the Simons Foundation, the Rauch Foundation, the Pritchard Foundation, and the Laurie Landeau Foundation.

\section{LITERATURE CITED}

Atalah J, Crowe TP (2012) Nutrient enrichment and variation in community structure on rocky shores: the potential of molluscan assemblages for biomonitoring. Estuar Coast Shelf Sci 99:162-170

Baumann H, Wallace RB, Tagliaferri T, Gobler CJ (2015) Large natural $\mathrm{pH}, \mathrm{CO}_{2}$ and $\mathrm{O}_{2}$ fluctuations in a temperate tidal salt marsh on diel, seasonal, and interannual time scales. Estuaries Coasts 38:220-231

Bibby R, Cleall-Harding P, Rundle S, Widdicombe S, Spicer $\mathrm{J}$ (2007) Ocean acidification disrupts induced defences in the intertidal gastropod Littorina littorea. Biol Lett 3: 699-701

Bishop T, Brand MD (2000) Processes contributing to metabolic depression in hepatopancreas cells from the snail Helix aspersa. J Exp Biol 203:3603-3612
Brady-Campbell MM, Campbell DB, Harlin MM (1984) Productivity of kelp (Laminaria spp.) near the southern limit in the Northwestern Atlantic Ocean. Mar Ecol Prog Ser 18:79-88

Cai WJ, Hu X, Huang WJ, Murrell MC and others (2011) Acidification of subsurface coastal waters enhanced by eutrophication. Nat Geosci 4:766-770

* Carefoot TH (1967) Growth and nutrition of Aplysia punctata feeding on a variety of marine algae. J Mar Biol Assoc UK 47:565-590

Chavanich S, Harris LG (2002) The influence of macroalgae on seasonal abundance and feeding preference of a subtidal snail, Lacuna vincta (Montagu) (Littorinidae) in the Gulf of Maine. J Molluscan Stud 68:73-78

* Chenelot H, Konar B (2007) Lacuna vincta (Mollusca, Neotaenioglossa) herbivory on juvenile and adult Nereocystis luetkeana (Heterokontophyta, Laminariales). Hydrobiologia 583:107-118

Coleman DW, Byrne M, Davis AR (2014) Molluscs on acid: gastropod shell repair and strength in acidifying oceans. Mar Ecol Prog Ser 509:203-211

* Doney SC, Fabry VJ, Feely RA, Kleypas JA (2009) Ocean acidification: the other $\mathrm{CO}_{2}$ problem. Annu Rev Mar Sci $1: 169-192$

*Dubois A, Iken K (2012) Seasonal variation in kelp phlorotannins in relation to grazer abundance and environmental variables in the Alaskan sublittoral zone. Algae 27:9-19

Falkenberg LJ, Russell BD, Connell SD (2013) Future herbivory: the indirect effects of enriched $\mathrm{CO}_{2}$ may rival its direct effects. Mar Ecol Prog Ser 492:85-95

Feely RA, Sabine CL, Hernandez-Ayon JM, Ianson D, Hales B (2008) Evidence for upwelling of corrosive 'acidified' water onto the continental shelf. Science 320:1490-1492

FFeely RA, Doney SC, Cooley SR (2009) Ocean acidification: present conditions and future changes in a high- $\mathrm{CO}_{2}$ world. Oceanography (Wash DC) 22:36-47

*Fonseca F, Bowsher CG, Stulen I (1997) Impact of elevated atmospheric $\mathrm{CO}_{2}$ on nitrate-reductase transcription and activity in leaves and roots of Plantago major. Physiol Plant 100:940-948

Fralick RA, Turgeon KW, Mathieson AC (1974) Destruction of kelp populations by Lacuna vincta (Montagu). Nautilus 88:112-114

*Fu FX, Tatters AO, Hutchins DA (2012) Global change and the future of harmful algal blooms in the ocean. Mar Ecol Prog Ser 470:207-233

* Gao K, Zheng Y (2010) Combined effects of ocean acidification and solar UV radiation on photosynthesis, growth, pigmentation and calcification of the coralline alga Corallina sessilis (Rhodophyta). Glob Chang Biol 16: 2388-2398

* Gazeau F, Quiblier C, Jansen JM, Gattuso JP, Middelburg JJ, Heip CHR (2007) Impact of elevated $\mathrm{CO}_{2}$ on shellfish calcification. Geophys Res Lett 34:L07603

* Gobler CJ, Baumann H (2016) Hypoxia and acidification in ocean ecosystems: coupled dynamics and effects on marine life. Biol Lett 12:20150976

*Gobler CJ, Merlo LR, Morrell BK, Griffith AW (2018) Temperature, acidification, and food supply interact to negatively affect the growth and survival of the forage fish, Menidia beryllina (inland silverside), and Cyprinodon variegatus (sheepshead minnow). Front Mar Sci 5:86

Gordillo FJL, Niella FX, Figueroa FL (2001) Non-photosynthetic enhancement of growth by high $\mathrm{CO}_{2}$ level in 
the nitrophilic seaweed Ulva rigida C. Agardh (Chlorophyta). Planta 213:64-70

*Hattenrath-Lehmann TK, Smith JL, Wallace RB, Merlo LR and others (2015) The effects of elevated $\mathrm{CO}_{2}$ on the growth and toxicity of field populations and cultures of the saxitoxin-producing dinoflagellate, Alexandrium fundyense. Limnol Oceanogr 60:198-214

Hauxwell J, Cebrian J, Furlong C, Valiela I (2001) Macroalgal canopies contribute to eelgrass (Zostera marina) decline in temperate estuarine ecosystems. Ecology 82: 1007-1022

Hendriks IE, Duarte CM, Álvarez M (2010) Vulnerability of marine biodiversity to ocean acidification: a meta-analysis. Estuar Coast Shelf Sci 86:157-164

Hepburn CD, Pritchard DW, Cornwall CE, McLeod RJ, Beardall J, Raven JA (2011) Diversity of carbon use strategies in a kelp forest community: implications for a high $\mathrm{CO}_{2}$ ocean. Glob Chang Biol 17:2488-2497

Hiroki K (1978) Resistance of marine gastropods to oxygen deficiency and hydrogen sulphide. Bol Fisiol Anim (Sao Paulo) 2:33-42

* Janiak DS, Whitlatch RB (2012) Epifaunal and algal assemblages associated with the native Chondrus crispus (Stackhouse) and the non-native Grateloupia turuturu (Yamada) in eastern Long Island Sound. J Exp Mar Biol Ecol 413:38-44

* Johnson CR, Mann KH (1986) The importance of plant defence abilities to the structure of subtidal seaweed communities: the kelp Lamanaria longicruris de la Pylaie survives grazing by the snail Lacuna vincta (Montagu) at high population densities. J Exp Mar Biol Ecol 97: 231-267

Kirkendale L, Saunders GW, Winberg P (2013) A molecular survey of Ulva (Chlorophyta) in temperate Australia reveals enhanced levels of cosmopolitanism. J Phycol 49: $69-81$

Kleypas JA, Buddemeier RW, Archer D, Gattuso JP, Langdon C, Opdyke BN (1999) Geochemical consequences of increased atmospheric carbon dioxide on coral reefs. Science 284:118-120

Krause-Jensen D, Duarte CM, Hendriks IE, Meire L, Blicher ME, Marbà N, Sejr MK (2015) Macroalgae contribute to nested mosaics of $\mathrm{pH}$ variability in a subarctic fjord. Biogeosciences 12:4895-4911

Krumhansl KA, Scheibling RE (2011) Spatial and temporal variation in grazing damage by the gastropod Lacuna vincta in Nova Scotian kelp beds. Aquat Biol 13: 163-173

Lapointe B, Barile PJ, Yentsch CS, Littler DS, Kakuk B (2004) The relative importance of nutrient enrichment and herbivory on macroalgal communities near Norman's Pond Cay, Exumas Cays, Bahamas: a 'natural' enrichment experiment. J Exp Mar Biol Ecol 298:275-301

Lindinger MI, Lauren DJ, McDonald DG (1984) Acid-base balance in the sea mussel, Mytilus edulis. III. Effects of environmental hypercapnia on intra- and extracellular acid-base balance. Mar Biol Lett 5:371-381

Maas AE, Elder LE, Dierssen HM, Seibel BA (2011) Metabolic response of Antarctic pteropods (Mollusca: Gastropoda) to food deprivation and regional productivity. Mar Ecol Prog Ser 441:129-139

Manno C, Morata N, Primicerio R (2012) Limacina retroversa's response to combined effects of ocean acidification and sea water freshening. Estuar Coast Shelf Sci 113:163-171
Marchant HK, Calosi P, Spicer JI (2010) Short-term exposure to hypercapnia does not compromise feeding, acid-base balance or respiration of Patella vulgata but surprisingly is accompanied by radula damage. J Mar Biol Assoc UK 90:1379-1384

Martel A, Chia FS (1991) Oviposition, larval abundance, in situ larval growth, and recruitment of the herbivore gastropod Lacuna vincta in kelp canopies in Barkely Sound, Vancouver Island (Britain Columbia). Mar Biol 110: 237-247

Melatunan S, Calosi P, Rundle SD, Moody AJ, Widdicombe $\mathrm{S}$ (2011) Exposure to elevated temperature and $\mathrm{pCO}_{2}$ reduces respiration rate and energy status in the periwinkle Littorina littorea. Physiol Biochem Zool 84: 583-594

Melzner F, Stange P, Trübenbach K, Thomsen J and others (2011) Food supply and seawater $p \mathrm{CO}_{2}$ impact calcification and internal shell dissolution in the blue mussel Mytilus edulis. PLOS ONE 6:e24223

* Melzner F, Jörn T, Koeve W, Oschlies A and others (2013) Future ocean acidification will be amplified by hypoxia in coastal habitats. Mar Biol 160:1875-1888

Millero FJ (2010) History of the equation of state of seawater. Oceanography (Wash DC) 23:18-33

* Molis M, Enge A, Karsten U (2010) Grazing impact of, and indirect interactions between mesograzers associated with kelp (Laminaria digitata). J Phycol 46:76-84

Nelson TA, Haberlin K, Nelson AV, Ribarich H and others (2008) Ecological and physiological controls of species composition in green macroalgal blooms. Ecology 89: 1287-1298

* O'Boyle S, McDermott G, Noklegaard T, Wilkes R (2013) A simple index of trophic status in estuaries and coastal bays based on measurements of $\mathrm{pH}$ and dissolved oxygen. Estuaries Coasts 36:158-173

* Ober GT, Thornber CS (2017) Divergent responses in growth and nutritional quality of coastal macroalgae to the combination of increased $\mathrm{pCO}_{2}$ and nutrients. Mar Environ Res 131:69-79

\%Odum EP, Smalley AE (1959) Comparison of population energy flow of a herbivorous and deposit-feeding invertebrate in a salt marsh ecosystem. Proc Natl Acad Sci USA 45:617-622

Olischläger M, Bartsch I, Gutow L, Wiencke C (2013) Effects of ocean acidification on growth and physiology of Ulva lactuca (Chlorophyta) in a rockpool-scenario. Phycological Res 61:180-190

*Palacios SL, Zimmerman RC (2007) Response of eelgrass Zostera marina to $\mathrm{CO}_{2}$ enrichment: possible impacts of climate change and potential for remediation of coastal habitats. Mar Ecol Prog Ser 344:1-13

*Pansch C, Schaub I, Havenhand J, Wahl M (2014) Habitat traits and food availability determine the response of marine invertebrates to ocean acidification. Glob Chang Biol 20:765-777

* Pedersen MF, Borum J (1997) Nutrient control of estuarine macroalgae: growth strategy and the balance between nitrogen requirements and uptake. Mar Ecol Prog Ser 161:155-163

* Pörtner HO, Reipschläger A, Heisler N (1998) Acid-base regulation, metabolism and energetics in Sipunculus nudus as a function of ambient carbon dioxide level. J Exp Biol 201:43-55

* Russell BD, Connell SD, Findlay HS, Tait K, Widdicombe S, Mieszkowska N (2013) Ocean acidification and rising 
temperatures may increase biofilm primary productivity but decrease grazer consumption. Philos Trans R Soc B 368:20120438

Seibel BA, Walsh PJ (2003) Biological impacts of deep-sea carbon dioxide injection inferred from indices of physiological performance. J Exp Biol 206:641-650

Shirayama Y, Thorton H (2005) Effect of increased atmospheric $\mathrm{CO}_{2}$ on shallow water marine benthos. J Geophys Res 110:C09S08

Swanson AK, Fox CH (2007) Altered kelp (Laminariales) phlorotannins and growth under elevated carbon dioxide and ultraviolet-B treatments can influence associated intertidal food webs. Glob Chang Biol 13:1696-1709

Talmage SC, Gobler CJ (2011) Effects of elevated temperature and carbon dioxide on the growth and survival of larvae and juveniles of three species of Northwest Atlantic bivalves. PLOS ONE 6:e26941

Taylor JD, Reid DG (1990) Shell microstructure and mineralogy of the Littorinidae: ecological and evolutionary significance. Hydrobiologia 193:199-215

Thomsen J, Casties I, Pansch C, Körtzinger A, Melzner F (2013) Food availability outweighs ocean acidification effects in juvenile Mytilus edulis: laboratory and field experiments. Glob Chang Biol 19:1017-1027

Todgham AE, Hofmann GE (2009) Transcriptomic response of sea urchin larvae Strongylocentrotus purpuratus to $\mathrm{CO}_{2}$ driven seawater acidification. J Exp Biol 212:2579-2594

Wahl M, Schneider Covachã S, Saderne V, Hiebenthal C, Müller JD, Pansch C, Sawall Y (2018) Macroalgae may mitigate ocean acidification effects on mussel calcification by increasing $\mathrm{pH}$ and its fluctuations. Limnol Oceanogr 63:3-21

Wakefield RL, Murray SN (1998) Factors influencing food

Editorial responsibility: Myron Peck, Hamburg, Germany choice by the seaweed-eating marine snail Norrisia norrisi (Trochidae). Mar Biol 130:631-642

Wallace RB, Gobler CJ (2015) Factors controlling blooms of microalgae and macroalgae (Ulva rigida) in a eutrophic, urban estuary: Jamaica Bay, NY, USA. Estuaries Coasts 38:519-533

*Wallace RB, Baumann H, Grear JS, Aller RC, Gobler CJ (2014) Coastal ocean acidification: the other eutrophication problem. Estuar Coast Shelf Sci 148:1-13

* Wood HL, Spicer JI, Widdicombe S (2008) Ocean acidification may increase calcification rates, but at a cost. Proc Biol Sci 275:1767-1773

Xu Z, Zou D, Gao K (2010) Effects of elevated $\mathrm{CO}_{2}$ and phosphorus supply on growth, photosynthesis and nutrient uptake in the marine macroalga Gracilaria lemaneiformis (Rhodophyta). Bot Mar 53:123-129

* Young CS, Gobler CJ (2016) Ocean acidification accelerates the growth of two bloom-forming macroalgae. PLOS ONE 11:e0155152

* Young CS, Gobler CJ (2018) The ability of macroalgae to mitigate the negative effects of ocean acidification on four species of North Atlantic bivalve. Biogeosciences 15:6167-6183

*Young CS, Peterson BJ, Gobler CJ (2018) The bloomforming macroalgae, Ulva, outcompetes the seagrass, Zostera marina, under high $\mathrm{CO}_{2}$ conditions. Estuaries Coasts 41:2340-2355

K Zhao J, Jiang P, Liu Z, Wei W and others (2013) The Yellow Sea green tides were dominated by one species, Ulva (Enteromorpha) prolifera, from 2007 to 2011. Chin Sci Bull 58:2298-2302

K Zimmerman RC, Kohrs DG, Steller DL, Alberte RS (1997) Impacts of $\mathrm{CO}_{2}$ enrichment on productivity and light requirements of eelgrass. Plant Physiol 115:599-607

Submitted: April 15, 2019; Accepted: July 25, 2019

Proofs received from author(s): September 23, 2019 